ARTICLE Evaluation of Non-Thermal Decontamination

\title{
Processes to Have the Equivalence of Thermal Process in Raw Ground Chicken
}

\section{Dopen access}

Received September 15, 2021

Revised November 24, 2021

Accepted November 30, 2021

*Corresponding author: Yohan Yoon

Department of Food and Nutrition,

Sookmyung Women's University,

Seoul 04310, Korea

Tel: +82-2-2077-7585

Fax: $+82-2-710-7585$

E-mail: yyoon@sm.ac.kr

*ORCID

Eunyoung Park

https://orcid.org/0000-0001-8331-1848

Sangeun Park

https://orcid.org/0000-0003-1607-1260

Jeong Hyeon Hwang

https://orcid.org/0000-0002-2470-3646

Ah Hyun Jung

https://orcid.org/0000-0002-5492-2196

Sung Hee Park

https://orcid.org/0000-0002-2755-2863

Yohan Yoon

https://orcid.org/0000-0002-4561-6218

\author{
Eunyoung Park ${ }^{1}$, Sangeun Park ${ }^{1}$, Jeong Hyeon Hwang ${ }^{2}$, Ah Hyun Jung ${ }^{2}$, \\ Sung Hee Park ${ }^{2}$, and Yohan Yoon ${ }^{1,3,{ }^{*}}$ \\ ${ }^{1}$ Department of Food and Nutrition, Sookmyung Women's University, Seoul 04310, \\ Korea \\ ${ }^{2}$ Department of Food Science and Technology, Seoul National University of Science \\ and Technology, Seoul 01811, Korea \\ ${ }^{3}$ Risk Analysis Research Center, Sookmyung Women's University, Seoul 04310, \\ Korea
}

\begin{abstract}
The present study was aimed at examining the antibacterial effects of nonthermal decontamination processes, which are equivalent to thermal treatment, to ensure microbiological safety of raw ground chicken. Escherichia coli or Salmonella were inoculated into $25 \mathrm{~g}$ of raw ground chicken samples. The raw ground chicken samples were non-treated or treated with high hydrostatic pressure (HHP) at $500 \mathrm{MPa}$ (1-7 min), light-emitting diode (LED) irradiation at $405 \mathrm{~nm}$ wavelength (30-120 min), and heat at $70^{\circ} \mathrm{C}, 90^{\circ} \mathrm{C}(1-60 \mathrm{~min})$, and $121^{\circ} \mathrm{C}(1-15 \mathrm{~min})$. E. coli and Salmonella cell counts were enumerated after treatments. Moreover, the color parameters of treated raw ground chicken were analyzed. HHP treatment reduced E. coli and Salmonella cell counts by more than $5 \mathrm{Log} \mathrm{CFU} / \mathrm{g}$ and more than $6 \mathrm{Log} \mathrm{CFU} / \mathrm{g}$ after $7 \mathrm{~min}$ and $1 \mathrm{~min}$, respectively; these effects were equivalent to those of thermal treatment. However, LED irradiation reduced Salmonella cell counts by only $0.9 \mathrm{Log}$ CFU/g after $90 \mathrm{~min}$ of treatment, and it did not reduce $E$. coli cell counts for $90 \mathrm{~min}$. Compared with those of the non-treated samples, the $\Delta E$ (total color difference) values of the samples treated with HHP were high, whereas the $\Delta E$ values of the samples treated with LED irradiation were low (1.932.98). These results indicate that despite color change by HHP treatment, HHP treatment at $500 \mathrm{MPa}$ could be used as a non-thermal decontamination process equivalent to thermal treatment.
\end{abstract}

Keywords heat-equivalent non-thermal technology, microbial quality, high hydrostatic pressure, ultraviolet light-emitting diode

\section{Introduction}

The most common pathogens contaminating poultry meat products are Escherichia coli and Salmonella. The chicken carcasses have been observed to have high contamination rates for E. coli $(77.5 \%)$ and Salmonella $(85 \%)$ (Yulistiani and

(C) Korean Society for Food Science of Animal Resources. This is an open access article distributed under the terms of the Creative Commons Attribution Non-Commercial License (http://creativecommons.org/licences/by-nc/3.0) which permits unrestricted non-commercial use, distribution, and reproduction in any medium, provided the original work is properly cited. 
Praseptiangga, 2019). E. coli are a gram-negative, facultatively anaerobic bacillus of the Enterobacteriaceae family (LenhardVidal et al., 2011). Salmonella are rod-shaped, gram-negative bacteria that are one of the most prevalent causes of foodborne illness globally (Ha et al., 2020). These pathogens may contaminate meat and meat products through hands of workers in slaughterhouses and during processing. Thus, thermal processing of poultry meat products is performed before its use in food.

Thermal processing enhances the shelf life of food products and ensures microbiological safety, but it may alter the structural-chemical composition, modify heat-labile components, affect the functional properties of food products, and change meat color. When consumed raw ready-to-eat meat such as Yukhoe, the meat color is the important index for consumer's acceptance. Thus, minimizing change in meat color is a requirement for a non-thermal decontamination process.

High hydrostatic pressure (HHP) processing is a non-destructive food preservation technology that efficiently eliminates food spoilage microorganisms without using chemicals (Kim et al., 2016). According to Garriga et al. (2004), HHP has the potential to be useful in the meat industry. HHP destroys microorganisms regardless of product geometry (Kim et al., 2016), along with increases in the safety of raw meat products and shelf life (Kruk et al., 2014).

Ultraviolet light-emitting diodes (LED) are considered one of the most influential alternatives to UV lamps because of their numerous advantages. Although antibacterial efficacy of LED is not comparable to that of UV light, significant antibacterial effects by LED irradiation has recently been reported ( $\mathrm{Li}$ et al., 2018). Previous studies have demonstrated significant microbial inactivation of LED on smoked salmon and papaya (Kim et al., 2017; Li et al., 2018). Furthermore, LED are costeffective and induce material degradation to a low extent ( $\mathrm{Li}$ et al., 2018). In addition, LED are environmentally friendly, and simple equipment is needed for LED lighting (Aoyagi et al., 2011).

Therefore, this study examined the antibacterial effect of non-thermal decontamination processes, which are equivalent to that of the thermal process, on raw ground chicken.

\section{Materials and Methods}

\section{Detection of E. coli and Salmonella in raw ground chicken}

To evaluate E. coli and Salmonella contamination levels in raw ground chickens in Korea, six raw ground chicken samples $(1 \mathrm{~kg})$ were purchased from grocery shop, and $25 \mathrm{~g}$ portions of raw ground chicken were transferred aseptically into sterile filter bags (3M, St. Paul, MN, USA). The filter bags were filled with $225 \mathrm{~mL}$ of $0.1 \%$ buffered peptone water (BPW; Becton Dickinson and Company, Sparks, MD, USA). The samples were macerated using a pummeler (BagMixer, Interscience, St. Nom, France) for $1 \mathrm{~min}$. One milliliter of the homogenate was put into a Petrifilm ${ }^{\mathrm{TM}}$ E. coli/Coliform count plate (3M). The parafilm was used to seal the plate, which was then incubated for $24 \mathrm{~h}$ at $37^{\circ} \mathrm{C}$. Typical blue colonies with obvious gas bubbles were carefully counted. In addition, for qualitative analysis of E. coli, $1 \mathrm{~mL}$ of the homogenate was added to E. coli broth (Becton Dickinson and Company) including Durham tube (Kisan Biotech, Seoul, Korea) and cultured for 24-48 h at $44.5^{\circ} \mathrm{C}$. Following streaking, the aliquot in the gas-producing tube was then streaked onto eosin methylene blue agar (EMB; Becton Dickinson and Company) and incubated for $24-48 \mathrm{~h}$ at $37^{\circ} \mathrm{C}$. Formation of typical colonies with luminescent metal color confirmed the presence of $E$. coli. One milliliter of the homogenate was spread out on the xylose lysine deoxycholate (XLD; Becton Dickinson and Company) agar, and the plate was sealed using parafilm before being incubated for $24 \mathrm{~h}$ at $37^{\circ} \mathrm{C}$ to count Salmonella. Colonies were carefully counted on XLD agar using typical black colonies. In addition, for qualitative analysis of Salmonella, the homogenate was incubated for $24 \mathrm{~h}$ at $37^{\circ} \mathrm{C}$. Further, aliquots containing $100 \mu \mathrm{L}$ were added to $10 \mathrm{~mL}$ Rappaport-Vassiliadis enrichment broth (Becton Dickinson and Company) and incubated for $24 \mathrm{~h}$ at $42^{\circ} \mathrm{C}$. 
The cultures were streaked onto XLD agar and then incubated for $24 \mathrm{~h}$ at $37^{\circ} \mathrm{C}$. Formation of typical black colonies confirmed the presence of Salmonella. The colonies on EMB and XLD agar were identified by 16S rRNA sequencing following amplification of the primers 27F (5' AGA GTT TGA TCM TGG CTC AG 3') and 1492R (5' TAC GGY TAC CTT GTT ACG ACT T 3'). The PCR was performed using an EF-Taq (Solgent, Daejeon, Korea), 20 ng genomic DNA was used as the template in a $30 \mu \mathrm{L}$ reaction mixture. The following PCR conditions used: initial denaturation for 2 min at $95^{\circ} \mathrm{C} ; 35$ cycles of amplification $\left(95^{\circ} \mathrm{C}\right.$ for $1 \mathrm{~min}, 55^{\circ} \mathrm{C}$ for $1 \mathrm{~min}$, and $72^{\circ} \mathrm{C}$ for $\left.1 \mathrm{~min}\right)$, and ending with $72^{\circ} \mathrm{C}$ for 10 min. A multiscreen filter plate was used to purify the enhanced products (Millipore, Bedford, MA, USA). The extension productcontaining DNA sample was mixed with $\mathrm{Hi}^{-\mathrm{Di}^{\mathrm{TM}}}$ formamide (Applied Biosystems, Foster City, CA, USA), and then incubated for $5 \mathrm{~min}$ at $95^{\circ} \mathrm{C}$ and for $5 \mathrm{~min}$ on ice before being examined with a DNA analyzer (Applied Biosystems).

\section{Inoculum preparation}

\section{E. coli}

E. coli strains (NCCP14037, NCCP14038, NCCP14039, NCCP15661, and ATCC43888) were cultured for $24 \mathrm{~h}$ in $10 \mathrm{~mL}$ tryptic soy broth (TSB; Becton Dickinson and Company) at $37^{\circ} \mathrm{C}$. The aliquots of these cultures $(100 \mu \mathrm{L})$ were transferred to $10 \mathrm{~mL}$ fresh TSB and sub-cultured at $37^{\circ} \mathrm{C}$ for $24 \mathrm{~h}$. The subcultures were combined and centrifuged at $1,912 \times \mathrm{g}$ for $15 \mathrm{~min}$ at $4^{\circ} \mathrm{C}$. The cell pellets were washed twice with $1 \times$ phosphate buffered saline (PBS; $\mathrm{pH} 7.4 ; 1.5 \mathrm{~g} / \mathrm{L} \mathrm{Na}_{2} \mathrm{HPO}_{4} \cdot 7 \mathrm{H}_{2} \mathrm{O}, 0.2 \mathrm{~g} / \mathrm{L}$ $\mathrm{KH}_{2} \mathrm{PO}_{4}, 0.2 \mathrm{~g} / \mathrm{L} \mathrm{KCl}$, and $8.0 \mathrm{~g} / \mathrm{L} \mathrm{NaCl}$ ) after removing the supernatants to obtain inoculum containing 8-9 Log CFU $/ \mathrm{mL}$.

\section{Salmonella}

Salmonella strains (NCCP12231, NCCP12236, NCCP12243, NCCP14544, and NCCP10140) were cultured in $10 \mathrm{~mL}$ TSB at $37^{\circ} \mathrm{C}$ for $24 \mathrm{~h}$. The aliquots of these cultures $(100 \mu \mathrm{L})$ were transferred to $10 \mathrm{~mL}$ fresh TSB and sub-cultured at $37^{\circ} \mathrm{C}$ for 24 $\mathrm{h}$. The subcultures were combined and centrifuged at $1,912 \times \mathrm{g}$ for $15 \mathrm{~min}$ at $4^{\circ} \mathrm{C}$. The cell pellets were washed twice with $1 \times$ PBS after removing the supernatants to obtain inoculum containing 8-9 Log CFU/mL.

\section{Inoculation}

To obtain 6-7 Log CFU/g on samples, aliquots containing $100 \mu \mathrm{L}$ of E. coli or Salmonella inoculum were inoculated on 25 $\mathrm{g}$ raw ground chicken samples and left for 15 min to allow attachment of the bacterial cells. The inoculated raw ground chicken samples were aseptically transferred to polyethylene pouches and vacuum-packaged (Postech, Haman, Korea). The vacuum-packaged samples were stored at $4^{\circ} \mathrm{C}$ until further treatment.

\section{Treatments}

\section{Thermal treatment}

The sample pouches were placed on a water bath rack and immediately immersed in circulating water bath at $70^{\circ} \mathrm{C}$ and $90^{\circ} \mathrm{C}$ for $1,15,30$, and $60 \mathrm{~min}$ and steam heated in an autoclave at $121^{\circ} \mathrm{C}$ for $1,4,7$, and $15 \mathrm{~min}$. After thermal treatment, the samples were aseptically transferred to filter bags containing $50 \mathrm{~mL}$ BPW and macerated with a pummeler. The homogenates were serially diluted with $9 \mathrm{~mL}$ BPW; $1 \mathrm{~mL}$ aliquots of the diluents were put into a Petrifilm ${ }^{\mathrm{TM}}$ E. coli/Coliform count plate for determination of E. coli cell counts, and $0.1 \mathrm{~mL}$ of the diluent was spread-plated onto XLD agar to enumerate Salmonella 
cells. The parafilm was used to seal the plate,which then incubated for $24 \mathrm{~h}$ at $37^{\circ} \mathrm{C}$. Followed by incubation, the bacterial colonies were carefully counted.

\section{HHP treatment}

The inoculated samples were loaded in a pressure chamber in an HP 300 high pressure machine (Hyperbaric, Burgos, Spain), and pressure was increased to $500 \mathrm{MPa}$ within $3 \mathrm{~min}$. The temperature of the pre-cooled samples increased up to $25^{\circ} \mathrm{C}$ owing to adiabatic heating during pressure build-up. The samples were pressurized at $500 \mathrm{MPa}$ for 1, 3, 5, and $7 \mathrm{~min}$. The pressure was immediately released to $0.1 \mathrm{MPa}$ post treatment, and all samples were placed on ice until analysis. The samples were macerated with a pummeler after being aseptically transferred to filter bags containing $50 \mathrm{~mL}$ BPW. The homogenates were serially diluted with $9 \mathrm{~mL}$ BPW; $1 \mathrm{~mL}$ aliquots of the diluents were put into a Petrifilm ${ }^{\mathrm{TM}}$ E. coli/Coliform count plate for determination of E. coli cell counts, and $0.1 \mathrm{~mL}$ of the diluent was spread-plated onto XLD agar to count Salmonella cells. The plate was sealed using parafilm and incubated for $24 \mathrm{~h}$ at $37^{\circ} \mathrm{C}$, and the bacterial colonies were carefully counted.

\section{LED treatment}

LED lamps (12 W, SWL-V2650, Sunwave, Suwon, Korea) with proportional integral derivative controller (ITC-100 VH, INKBIRD Tech, Shenzhen, China) were used. Five lamps were installed in a refrigerator $(600 \mathrm{~mm} \times 600 \mathrm{~mm})$. The raw ground chicken samples were placed at the distance of $50 \mathrm{~mm}$ from the lamps, and they were treated at $405 \mathrm{~nm}$ for 30,60, 90, and 120 min. UV intensity was measured using a spectrometer (StellarNet BLK-C, Stellar Net, Tampa, FL, USA). An optical probe of a spectrometer was placed at distance of $50 \mathrm{~mm}$ from the lamps, and the light intensity was then integrated using a auto digitizer. UV intensity was calculated as $2.8,5.6,8.4$, and $11.2 \mathrm{~J} / \mathrm{cm}^{2}$ under LED irradiation for 30, 60, 90, and $120 \mathrm{~min}$, respectively. After LED irradiation, the samples were aseptically transferred to a filter bag containing $50 \mathrm{~mL}$ BPW and macerated using a pummeler. The homogenates were serially diluted with $9 \mathrm{~mL} \mathrm{BPW} ; 1 \mathrm{~mL}$ aliquots of the diluents were put into a Petrifilm ${ }^{\mathrm{TM}}$ E. coli/Coliform count plate for determination of $E$. coli cell counts, and $0.1 \mathrm{~mL}$ of the diluent was spreadplated onto XLD agar to count Salmonella cells. The plate was sealed with parafilm and incubated at $37^{\circ} \mathrm{C}$ for $24 \mathrm{~h}$. Followed by incubation, the bacterial colonies were carefully counted.

\section{Color analysis}

To evaluate if HHP and LED treatment affect on the meat color. The lightness $\left(\mathrm{L}^{*}\right)$, redness $\left(\mathrm{a}^{*}\right)$, and yellowness $\left(\mathrm{b}^{*}\right)$ in the samples treated with HHP or LED were measured using a colorimeter (CR-10, Konica Minolta Sensing, Osaka, Japan). It had the illuminant of D65, observer angle of $2^{\circ}$ and aperture diameter of $8 \mathrm{~mm}$. The total color difference $(\Delta E)$ was estimated using the following equation to determine the overall color change compared with that of the control.

$$
\Delta E=\sqrt{\left(L *-L *_{0}\right)^{2}+\left(a *-a *_{0}\right)^{2}+\left(b *-b *_{0}\right)^{2}}
$$

where $\mathrm{L}_{0}, \mathrm{a}_{0}{ }_{0}$, and $\mathrm{b}_{0}{ }_{0}$ represent the readings at $0 \mathrm{~h}$, and $\mathrm{L}^{*}, \mathrm{a}^{*}$, and $\mathrm{b}^{*}$ represent the individual readings after the defined treatments.

\section{Statistical analysis}

The antibacterial effects and color parameters data were analyzed using the general linear model in SAS version 9.4 (SAS 
Institute, Cary, NC, USA). The differences among the least square means were calculated using a paired $t$-test with at $\alpha=0.05$ significance level.

\section{Results and Discussion}

\section{E. coli and Salmonella prevalence in raw ground chicken}

E. coli were detected in all tested samples at $2.2 \pm 0.5 \mathrm{Log}$ CFU/g, whereas Salmonella were not detected in any of the samples. According to the Eyi and Arslan (2012), E. coli were detected in $87.5 \%$ of poultry samples at $3.3 \mathrm{Log}$ CFU/g. Eyi and Arslan (2012) reported predominant contamination of carcasses of animals and birds with E. coli and suggested that contamination of meat and meat products with E. coli are likely during preparation and sale also. Although the prevalence of Salmonella in retail chicken in previous studies was reported as 53.3\% in Vietnam (Van et al., 2007), 36.5\% in Belgium (Uyttendaele et al., 1999), and 42.3\% in Korea (Hyeon et al., 2011), the result from our study showed no positive samples for Salmonella. This difference might be caused by washing chicken carcasses with sodium hypochlorite in Korea. MFDS (2019) and Yoon et al. (2014) also showed very low prevalence of Salmonella in chicken. Collectively, these results suggest the importance of decontamination processes in foods containing raw chicken.

\section{Antibacterial effects}

\section{Thermal treatment}

In non-heated raw ground chicken samples, E. coli cell counts were $6.6 \mathrm{Log} \mathrm{CFU} / \mathrm{g}$, and these decreased to $6.2 \mathrm{Log}$ CFU/g after $1 \mathrm{~min}, 0.6 \mathrm{Log} \mathrm{CFU} / \mathrm{g}$ after $15 \mathrm{~min}$, and limit of detection (LOD; $0.5 \mathrm{Log} \mathrm{CFU} / \mathrm{g}$ ) after $30 \mathrm{~min}$ at $70^{\circ} \mathrm{C}$ (Fig. 1A). Salmonella cell counts in non-heated raw ground chicken samples were $6.8 \mathrm{Log} \mathrm{CFU} / \mathrm{g}$, which also decreased to $6.3 \mathrm{Log}$ CFU/g after $1 \mathrm{~min}, 0.8 \mathrm{Log}$ CFU/g after $15 \mathrm{~min}, 0.6 \mathrm{Log} \mathrm{CFU} / \mathrm{g}$ after $30 \mathrm{~min}$, and LOD after $60 \mathrm{~min}$ at $70^{\circ} \mathrm{C}$ (Fig. 1B). These

(A)

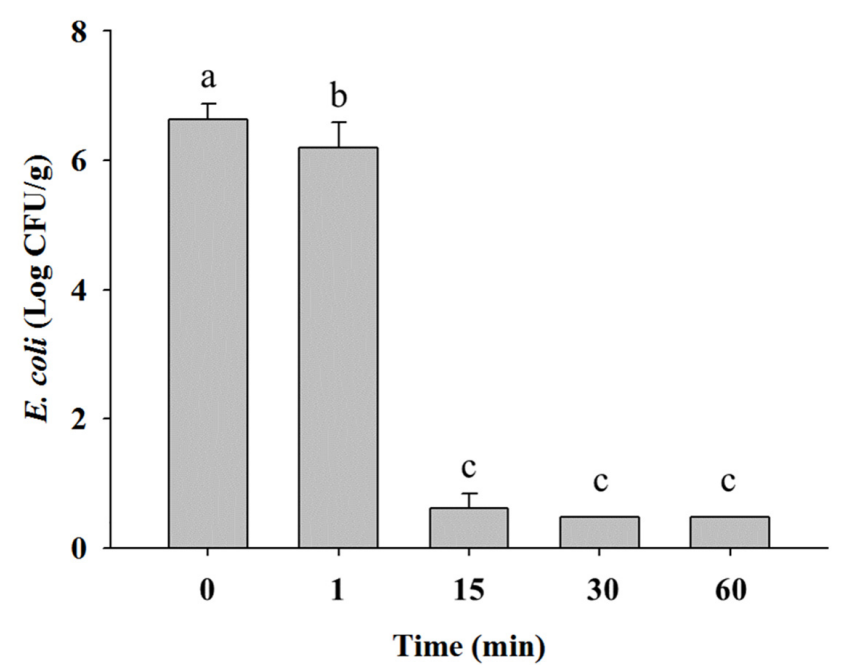

(B)

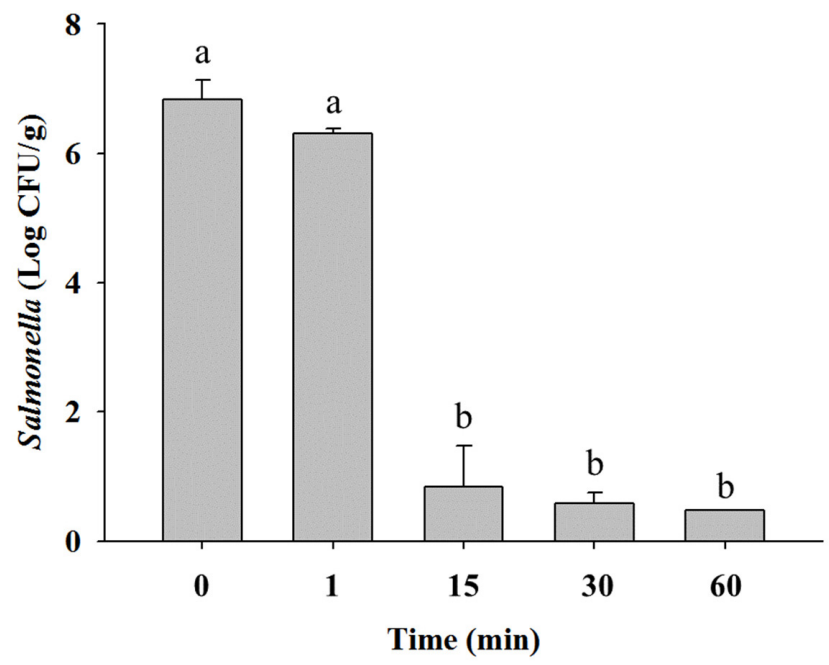

Fig. 1. Escherichia coli (A) and Salmonella cell counts (B) in raw ground chicken samples after thermal treatment at $70^{\circ} \mathrm{C}$. Data shown are mean \pm SD. ${ }^{a-c}$ Means with different letters are significantly different $(p<0.05)$. 
results showed that E. coli and Salmonella in raw ground chicken were destroyed within 30 min and 60 min of thermal treatment at $70^{\circ} \mathrm{C}$, respectively. Thermal treatment at $90^{\circ} \mathrm{C}$ resulted in decrease in $E$. coli cell counts in raw ground chicken samples to 6.3 Log CFU/g after $1 \mathrm{~min}$ and LOD after $15 \mathrm{~min}$ compared with $6.6 \mathrm{Log}$ CFU/g in untreated samples (Fig. 2A). Similarly, Salmonella cell counts significantly decreased to $6.2 \mathrm{Log}$ CFU/g after $1 \mathrm{~min}$ and LOD after 15 min after treatment at $90^{\circ} \mathrm{C}$ from the initial concentration of $6.8 \mathrm{Log} \mathrm{CFU} / \mathrm{g}$ (Fig. 2B). These findings showed that E. coli and Salmonella in raw ground chicken were destroyed within $15 \mathrm{~min}$ at $90^{\circ} \mathrm{C}$. Moreover, both E. coli and Salmonella cell counts in raw ground chicken samples were estimated to reach LOD after $1 \mathrm{~min}$ when heated at $121^{\circ} \mathrm{C}$ (Fig. 3A and 3B). This shows that E. coli and Salmonella in raw ground chicken can be eliminated within 1 min by heating at $121^{\circ} \mathrm{C}$.

(A)

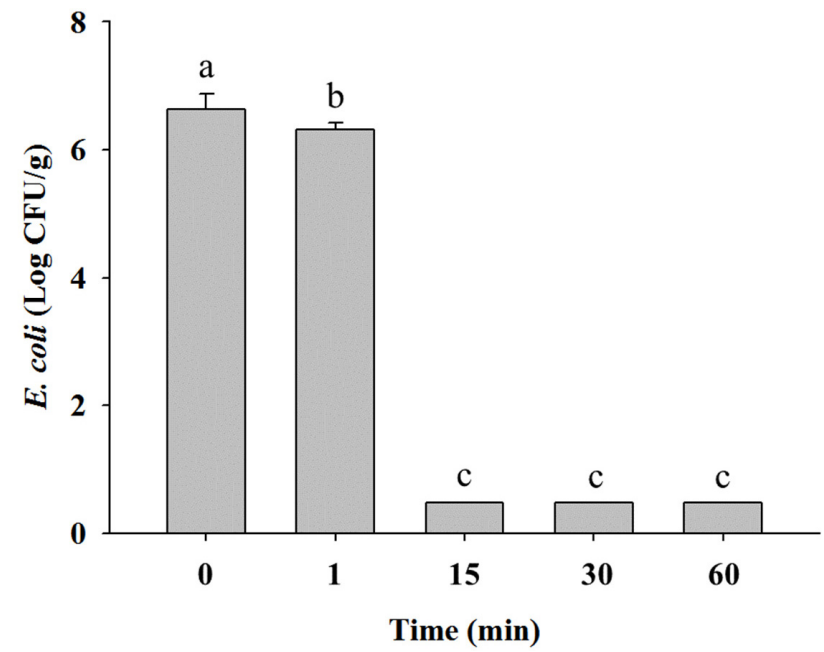

(B)

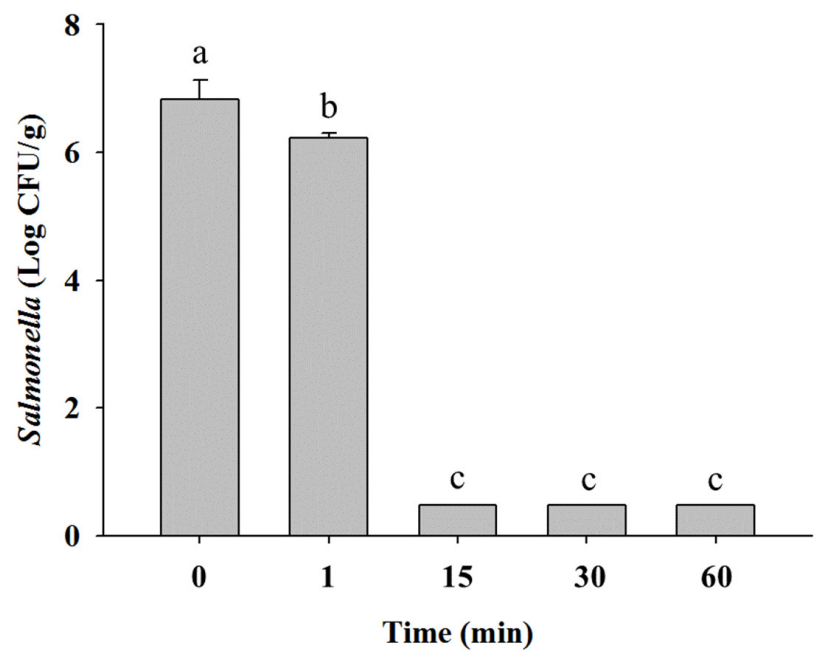

Fig. 2. Escherichia coli (A) and Salmonella cell counts (B) in raw ground chicken samples after thermal treatment at $90^{\circ} \mathrm{C}$. Data shown are mean \pm SD. ${ }^{a-c}$ Means with different letters are significantly different $(p<0.05)$.

(A)

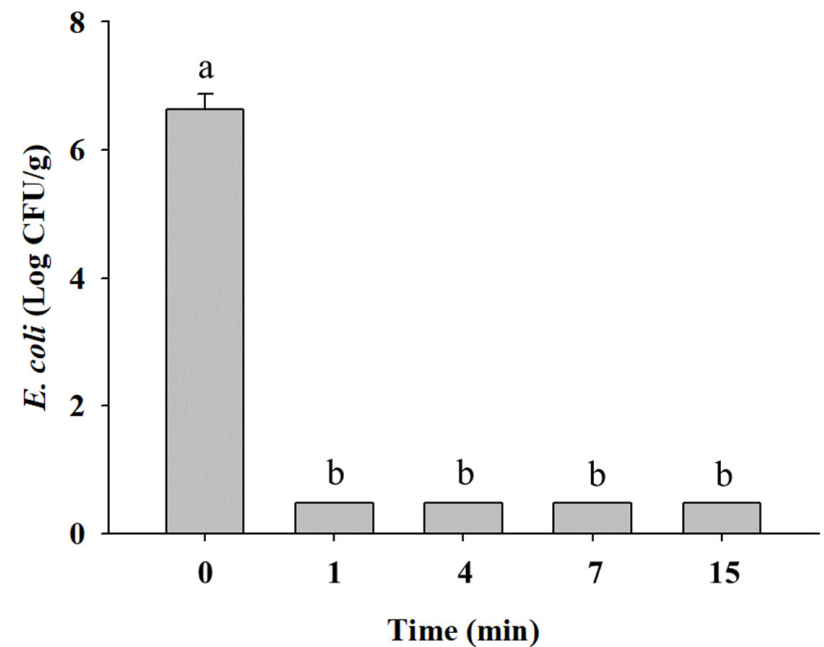

(B)

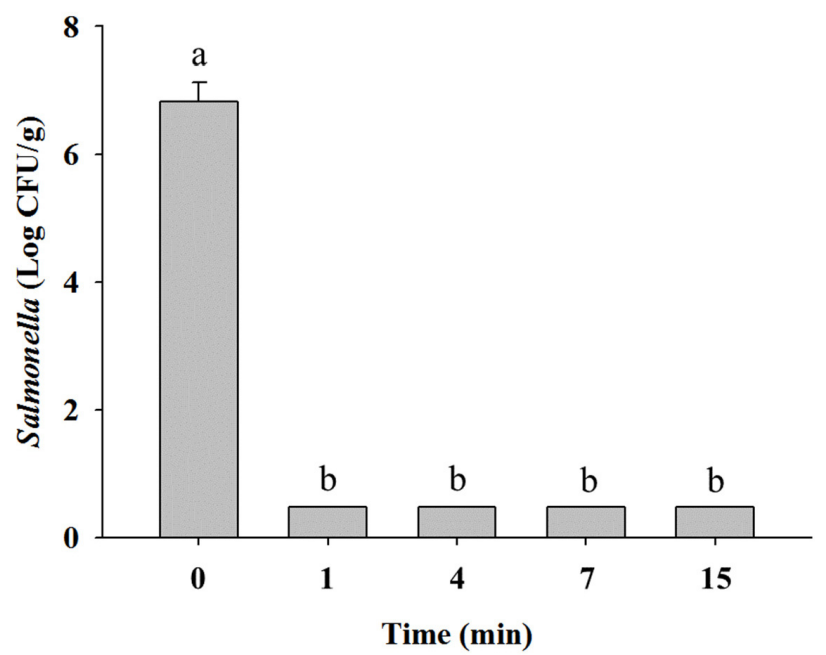

Fig. 3. Escherichia coli (A) and Salmonella cell counts (B) in raw ground chicken samples after thermal treatment at $121^{\circ} \mathrm{C}$. Data shown are mean $\pm S D$. ${ }^{a, b}$ Means with different letters are significantly different $(p<0.05)$. 


\section{HHP treatment}

HHP treatment reduced E. coli cell counts in raw ground chicken samples to $4.8 \mathrm{Log}$ CFU/g after $1 \mathrm{~min}, 3.4 \mathrm{Log}$ CFU/g after $3 \mathrm{~min}, 2.7 \mathrm{Log}$ CFU/g after $5 \mathrm{~min}$, and $0.9 \mathrm{Log}$ CFU/g after $7 \mathrm{~min}$ from the initial concentration of $6.7 \mathrm{Log}$ CFU/g (Fig. 4A). Salmonella cell counts decreased to $0.8 \mathrm{Log} \mathrm{CFU} / \mathrm{g}$ after $1 \mathrm{~min}$ and LOD after $3 \mathrm{~min}$ of HHP treatment from the initial concentration of $6.5 \mathrm{Log}$ CFU/g (Fig. 4B). This shows that Salmonella are more sensitive to HHP than E. coli. HHP treatment causes many changes in microbial cell membranes, resulting in lysis, nuclear material alteration, osmotic changes, and other modifications, finally leading to pathogen eradication (Mackey et al., 1994). Jung et al. (2012) and Kruk et al. (2011) reported that HHP of 450-600 MPa almost completely eliminated E. coli and Salmonella. These results indicate that 7-min HHP treatment at $500 \mathrm{MPa}$ can reduce both E. coli and Salmonella cell counts, equivalent to thermal treatment for $60 \mathrm{~min}$ at $70^{\circ} \mathrm{C}$, $15 \mathrm{~min}$ at $90^{\circ} \mathrm{C}$, and $1 \mathrm{~min}$ at $121^{\circ} \mathrm{C}(\mathrm{p}<0.05)$.

\section{LED irradiation}

E. coli cell counts in raw ground chicken samples before and after LED irradiation at $405 \mathrm{~nm}$ was not significantly different (Fig. 5A). LED irradiation for 90 min reduced Salmonella cell counts in raw ground chicken only by 0.9 Log CFU/g ( $<<0.05$ ), but it did not reduce E. coli cell counts for 90 min (Fig. 5B). According to Kim et al. (2017), Salmonella cell counts in fresh-cut papaya were reduced by 1-1.2 Log CFU/ $\mathrm{cm}^{2}$ when exposed to $405 \mathrm{~nm}$ LED for $48 \mathrm{~h}$. Li et al. (2018) suggested that LED irradiation at $405 \mathrm{~nm}$ for $8 \mathrm{~h}$ reduced a $0.5-\mathrm{Log} \mathrm{CFU} / \mathrm{cm}^{2}$ of Salmonella cell counts in ready-to-eat fresh salmon. These results indicate that LED irradiation has no significant effect on microbial reduction compared with thermal treatment, and Salmonella are more sensitive to LED irradiation than E. coli.

\section{Color of raw ground chicken after treatments}

\section{HHP treatment}

The parameters of chicken color $\left(\mathrm{L}^{*}, \mathrm{a}^{*}\right.$, and $\left.\mathrm{b}^{*}\right)$ are shown in Table 1 . The $\mathrm{L}^{*}$ values were high $(\mathrm{p}<0.05)$ in the HHP-

(A)

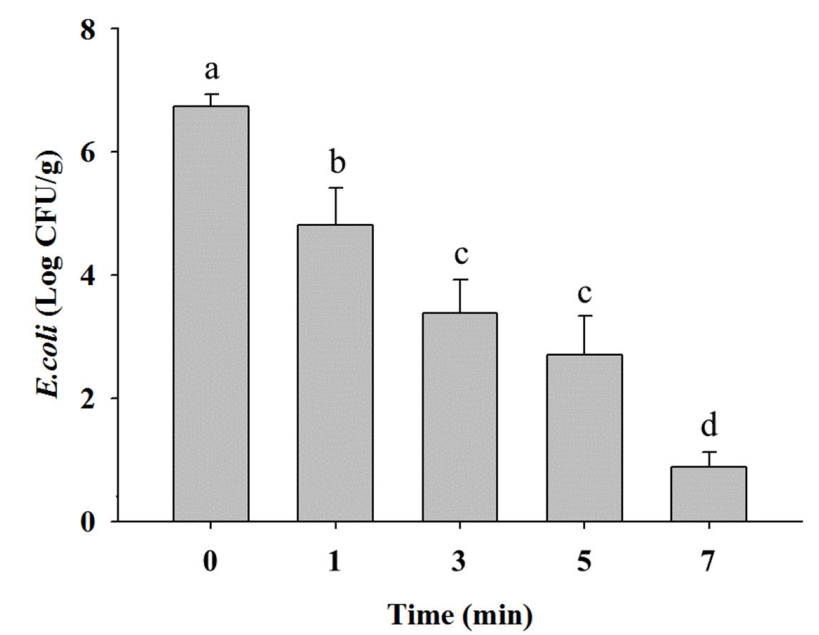

(B)

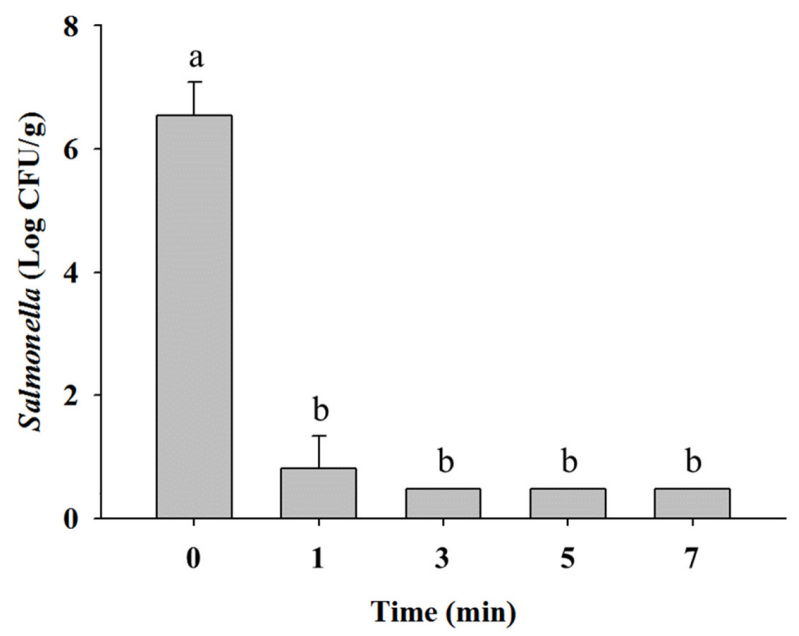

Fig. 4. Escherichia coli (A) and Salmonella cell counts (B) in raw ground chicken samples after high hydrostatic pressure at 500 MPa. Data shown are mean \pm SD. ${ }^{a-d}$ Means with different letters are significantly different $(p<0.05)$. 
(A)

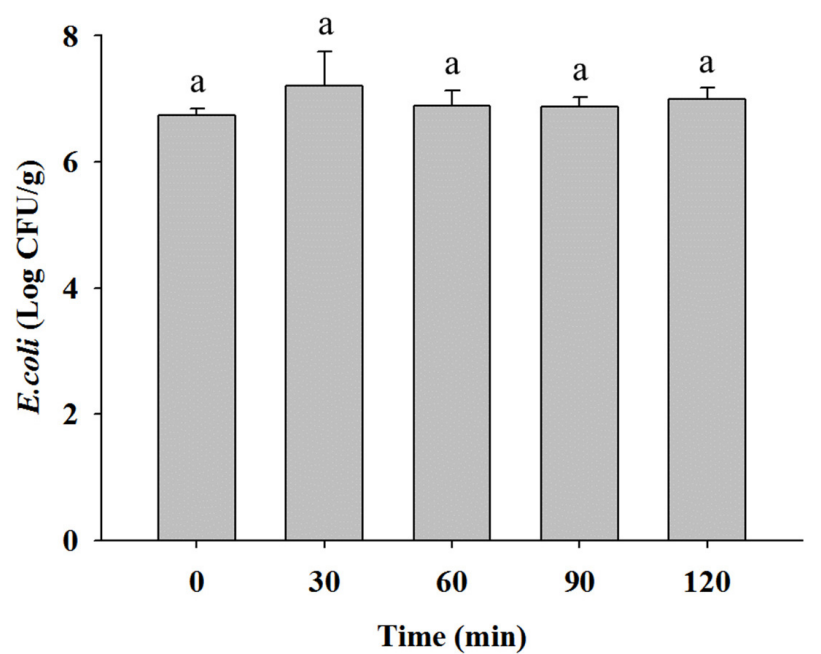

(B)

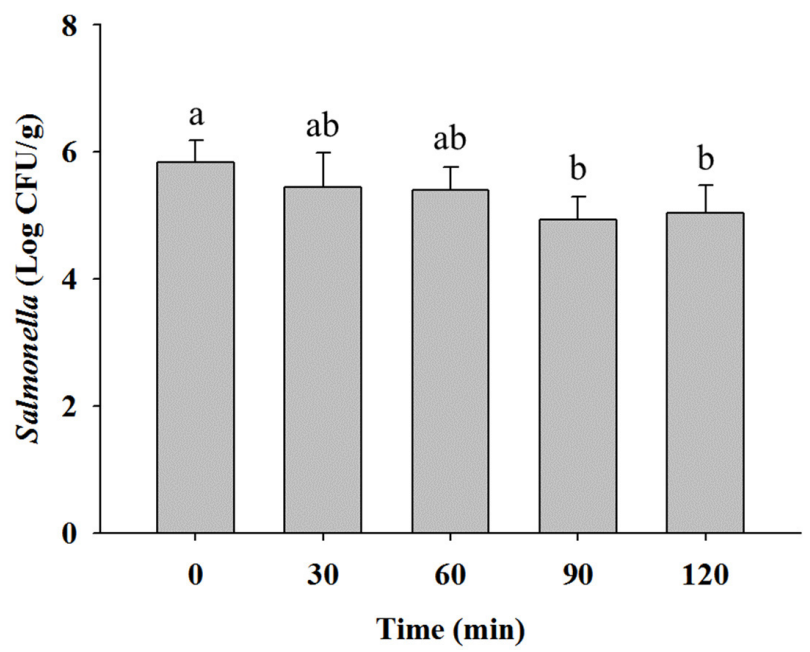

Fig. 5. Escherichia coli (A) and Salmonella cell counts (B) in raw ground chicken samples after light-emitting diode at $405 \mathrm{~nm}$. Data shown are mean $\pm S D$. ${ }^{a, b}$ Means with different letters are significantly different $(p<0.05)$.

Table 1. The color parameters (mean \pm SD) of the raw ground chicken samples after high hydrostatic pressure treatment at $500 \mathrm{MPa}$

\begin{tabular}{|c|c|c|c|c|c|}
\hline \multirow{2}{*}{ Property } & \multicolumn{5}{|c|}{ HHP treatment (min) } \\
\hline & 0 & 1 & 3 & 5 & 7 \\
\hline $\mathrm{L}^{*}$ & $44.63 \pm 2.15^{b}$ & $52.90 \pm 1.51^{\mathrm{a}}$ & $52.77 \pm 0.75^{\mathrm{a}}$ & $54.47 \pm 2.50^{\mathrm{a}}$ & $55.43 \pm 0.76^{\mathrm{a}}$ \\
\hline$a^{*}$ & $27.73 \pm 2.42^{\mathrm{a}}$ & $22.50 \pm 2.36^{\mathrm{b}}$ & $23.70 \pm 1.44^{\mathrm{b}}$ & $21.17 \pm 2.81^{\mathrm{b}}$ & $20.10 \pm 1.41^{\mathrm{b}}$ \\
\hline$b^{*}$ & $18.27 \pm 2.63^{\mathrm{a}}$ & $20.27 \pm 0.21^{\mathrm{a}}$ & $20.13 \pm 1.04^{\mathrm{a}}$ & $19.93 \pm 0.93^{\mathrm{a}}$ & $20.43 \pm 0.51^{\mathrm{a}}$ \\
\hline$\Delta E$ & - & $10.31 \pm 2.51$ & $10.00 \pm 3.23$ & $12.48 \pm 2.81$ & $13.54 \pm 1.97$ \\
\hline
\end{tabular}

${ }^{a, b}$ Means with different superscript letters in a row are significantly different $(\mathrm{p}<0.05)$.

HHP, high hydrostatic pressure; $\Delta E$, total color difference.

treated raw ground chicken samples. The $\mathrm{L}^{*}$ value represents the light-dark spectrum with a range from 0 (black) to 100 (white), which is closely related to the browning level of the samples (Pathare et al., 2013). The $\mathrm{a}^{*}$ values were low $(\mathrm{p}<0.05)$ in the HHP-treated raw ground chicken samples. Wang et al. (2018) reported a* value as the most important color parameter for fresh meat, which is defined as the red-green spectrum with a range of -60 (green) to +60 (red). The alterations in $\mathrm{L}^{*}$ and $a^{*}$ values following HHP treatment were caused by the oxidation of ferrous myoglobin to metmyoglobin, which represents the effect of pressure on globin denaturation and structural rearrangement (Carlez et al., 1995; Fraqueza et al., 2019; Szerman et al., 2011). The $b^{*}$ value is defined as the blue-yellow spectrum with a range from -60 (blue) to +60 (yellow) (Wang et al., 2018). In our study, the $\mathrm{b}^{*}$ values were not significantly different among the samples. The total color difference $(\Delta E)$ represented the magnitude of the overall color difference between the non-HHP and HHP-treated samples. The $\Delta E$ values in HHP-treated raw ground chicken samples ranged between 10.00-13.54 (Table 1). According to the study by Kim et al. (2016), $\Delta E$ values $>12$ indicates a significant color difference. Thus, the HHP-treated raw ground chicken samples showed a significant color difference from the non-HHP-treated samples (Table 1).

\section{LED irradiation}

The $\mathrm{L}^{*}$ values decreased in the LED-irradiated raw ground chicken samples, whereas the $\mathrm{a}^{*}$ values increased $(\mathrm{p}<0.05$; 
Table 2. The color parameters (mean \pm SD) of the raw chicken samples after light emitting diode irradiation at $405 \mathrm{~nm}$

\begin{tabular}{lccccc}
\hline \multirow{2}{*}{ Property } & \multicolumn{5}{c}{$405 \mathrm{~nm}$ LED irradiation (min) } \\
\cline { 2 - 6 } & 0 & 30 & 60 & 90 & 120 \\
$\mathrm{~L}^{*}$ & $40.50 \pm 0.69^{\mathrm{a}}$ & $39.20 \pm 0.26^{\mathrm{b}}$ & $39.87 \pm 0.42^{\mathrm{ab}}$ & $39.93 \pm 0.76^{\mathrm{ab}}$ & $39.97 \pm 0.75^{\mathrm{ab}}$ \\
$\mathrm{a}^{*}$ & $23.90 \pm 0.40^{\mathrm{c}}$ & $26.07 \pm 0.67^{\mathrm{a}}$ & $25.27 \pm 0.80^{\mathrm{ab}}$ & $24.73 \pm 0.67^{\mathrm{bc}}$ & $25.13 \pm 0.12^{\mathrm{ab}}$ \\
$\mathrm{b}^{*}$ & $19.87 \pm 0.96^{\mathrm{b}}$ & $21.20 \pm 0.46^{\mathrm{a}}$ & $21.83 \pm 0.15^{\mathrm{a}}$ & $21.30 \pm 0.53^{\mathrm{a}}$ & $22.07 \pm 1.10^{\mathrm{a}}$ \\
$\Delta E$ & - & $2.98 \pm 0.86$ & $2.62 \pm 1.26$ & $1.93 \pm 1.60$ & $2.90 \pm 0.91$ \\
\hline
\end{tabular}

${ }^{a-c}$ Means with different superscript letters in a row are significantly different $(\mathrm{p}<0.05)$.

LED, light-emitting diode; $\Delta E$, total color difference.

Table 2). Our findings were comparable to those reported by Chun et al. (2010) that a* values increased in the chicken breast after UV irradiation. The $\mathrm{b}^{*}$ values increased $(\mathrm{p}<0.05)$ in the LED-irradiated raw ground chicken samples (Table 2). The $\Delta E$ values in LED-irradiated raw ground chicken samples were 1.93-2.98 (Table 2). Francis and Clydesdale (1975) suggested that color difference is not clearly distinguished by human eyes when $\Delta E$ values $<3$. Thus, the results indicate that LED irradiation slightly changed the color of raw ground chicken compared with that of the non-irradiated samples.

\section{Conclusion}

In this study, HHP treatment at $500 \mathrm{MPa}$ can destroy more than $5 \mathrm{Log} \mathrm{CFU} / \mathrm{g}$ of $E$. coli cell counts for 7 min and more than $6 \mathrm{Log}$ CFU/g of Salmonella cell counts for $1 \mathrm{~min}$; these effects are equivalent to thermal treatment of raw ground chicken at $70^{\circ} \mathrm{C}$ for $60 \mathrm{~min}, 90^{\circ} \mathrm{C}$ for $15 \mathrm{~min}$, and $121^{\circ} \mathrm{C}$ for $1 \mathrm{~min}$. However, LED irradiation at $405 \mathrm{~nm}$ does not have the significant antibacterial effects as much as by the thermal treatment. Collectively, although HHP treatment causes color change, HHP treatment at $500 \mathrm{MPa}$ for more than $7 \mathrm{~min}$ can be used as a non-thermal decontamination process, equivalent to thermal treatment, to improve the microbiological safety of raw ground chicken.

\section{Conflicts of Interest}

The authors declare no potential conflicts of interest.

\section{Acknowledgments}

This work was supported by Korea Institute of Planning and Evaluation for Technology in Food, Agriculture and Forestry (IPET) through High Value-added Food Technology Development Program, funded by Ministry of Agriculture, Food and Rural Affairs (MAFRA) (320033-01).

\section{Author Contributions}

Conceptualization: Park E. Data curation: Park E, Park S. Formal analysis: Park E, Park S. Methodology: Park E, Park S. Software: Park S, Park E. Validation: Hwang JH, Jung AH. Investigation: Park E, Park S, Hwang JH, Jung AH. Writing original draft: Park E, Yoon Y. Writing - review \& editing: Park E, Park S, Hwang JH, Jung AH, Park SH, Yoon Y. 


\section{Ethics Approval}

This article does not require IRB/IACUC approval because there are no human and animal participants.

\section{References}

Aoyagi Y, Takeuchi M, Yoshida K, Kurouchi M, Yasui N, Kamiko N, Araki T, Nanishi Y. 2011. Inactivation of bacterial viruses in water using deep ultraviolet semiconductor light-emitting diode. J Environ Eng 137:1215-1218.

Carlez A, Veciana-Nogues T, Cheftel JC. 1995. Changes in colour and myoglobin of minced beef meat due to high pressure processing. LWT-Food Sci Technol 28:528-538.

Chun HH, Kim JY, Lee BD, Yu DJ, Song KB. 2010. Effect of UV-C irradiation on the inactivation of inoculated pathogens and quality of chicken breasts during storage. Food Control 21:276-280.

Eyi A, Arslan S. 2012. Prevalence of Escherichia coli in retail poultry meat, ground beef and beef. Med Weter 68:237-240.

Francis FJ, Clydesdale FM. 1975. Food colorimetry: Theory and applications. AVI, Westport, CT, USA. pp 73-111.

Fraqueza MJ, Martins C, Gama LT, Fernande MH, Fernandes MJ, Ribeiro MHL, Hernando BR, Barreto AS, Alfaia AJI. 2019. High hydrostatic pressure and time effects on hygienic and physical characteristics of natural casings and condiments used in the processing of cured meat sausage. Innov Food Sci Emerg Technol 58:102242.

Garriga M, Grèbol N, Aymerich MT, Monfort JM, Hugas M. 2004. Microbial inactivation after high-pressure processing at $600 \mathrm{MPa}$ in commercial meat products over its shelf life. Innov Food Sci Emerg Technol 5:451-457.

Ha J, Park E, Kim JS, Lee S, Kim S, Lee J, Choi Y, Yoon Y, Oh H, Kim Y, Lee Y, Seo Y, Kang J. 2020. Prevalence of Salmonella in cucumbers, antibiotic and acid resistances and description of the kinetic behavior with dynamic model during storage. J Food Saf 40:e12760.

Hyeon JY, Chon JW, Hwang IG, Kwak HS, Kim MS, Kim SK, Choi IS, Song CS, Park C, Seo KH. 2011. Prevalence, antibiotic resistance, and molecular characterization of Salmonella serovars in retail meat products. J Food Prot 74:161166.

Jung S, Yun HJ, Kim HJ, Ham JS, Kim IS, Lee MH, Jo C. 2012. Inactivation efficiency of Escherichia coli and Listeria monocytogenes in ground pork by combination of natural food ingredients and high pressure processing. Korean J Food Sci Anim Resour 32:1-5.

Kim HJ, Yong HI, Lee HJ, Jung S, Kwon JH, Heo KN, Jo C. 2016. Identification of microorganisms in duck meat products available in Korea and the effect of high hydrostatic pressure. Korean J Food Sci Anim Resour 36:283-288.

Kim MJ, Bang WS, Yuk HG. 2017. 405 \pm 5 nm light emitting diode illumination causes photodynamic inactivation of Salmonella spp. on fresh-cut papaya without deterioration. Food Microbiol 62:124-132.

Kruk ZA, Kim HJ, Kim YJ, Rutley DL, Jung S, Lee SK, Jo C. 2014. Combined effects of high pressure processing and addition of soy sauce and olive oil on safety and quality characteristics of chicken breast meat. Asian-Australas J Anim Sci 27:256-265.

Kruk ZA, Yun H, Rutley DL, Lee EJ, Kim YJ, Jo C. 2011. The effect of high pressure on microbial population, meat quality and sensory characteristics of chicken breast fillet. Food Control 22:6-12.

Lenhard-Vidal A, Cardoso RF, Pádua RAF, Siqueira VLD. 2011. High prevalence rate of extended-spectrum beta-lactamases (ESBL) among Enterobacteriaceae in a small Brazilian public hospital. Braz J Pharm Sci 47:701-707.

Li X, Kim MJ, Yuk HG. 2018. Influence of $405 \mathrm{~nm}$ light-emitting diode illumination on the inactivation of Listeria 
monocytogenes and Salmonella spp. on ready-to-eat fresh salmon surface at chilling storage for $8 \mathrm{~h}$ and their susceptibility to simulated gastric fluid. Food Control 88:61-68.

Mackey BM, Forestière K, Isaacs NS, Stenning R, Brooker B. 1994. The effect of high hydrostatic pressure on Salmonella Thompson and Listeria monocytogenes examined by electron microscopy. Lett Appl Microbiol 19:429-432.

Ministry of Food and Drug Safety [MFDS]. 2019. Risk assessment and reduction of Salmonella species in livestock products. Available from: https://scienceon.kisti.re.kr/srch/selectPORSrchReport.do?cn=TRKO202000029897. Accessed at Nov 18, 2021.

Pathare PB, Opara UL, Al-Said FAJ. 2013. Colour measurement and analysis in fresh and processed foods: A review. Food Bioprocess Technol 6:36-60.

Szerman N, Barrio Y, Schroeder B, Martinez P, Sancho AM, Sanow C, Vaudagna SR. 2011. Effect of high hydrostatic pressure treatments on physicochemical properties, microbial quality and sensory attributes of beef carpaccio. Procedia Food Sci 1:854-861.

Uyttendaele M, De Troy P, Debevere J. 1999. Incidence of Salmonella, Campylobacter jejuni, Campylobacter coli, and Listeria monocytogenes in poultry carcasses and different types of poultry products for sale on the Belgian retail market. J Food Prot 62:735-740.

Van TTH, Moutafis G, Istivan T, Tran LT, Coloe PJ. 2007. Detection of Salmonella spp. in retail raw food samples from Vietnam and characterization of their antibiotic resistance. Appl Environ Microbiol 73:6885-6890.

Wang J, Law CL, Nema PK, Zhao JH, Liu ZL, Deng LZ, Gao ZJ, Xiao HW. 2018. Pulsed vacuum drying enhances drying kinetics and quality of lemon slices. J Food Eng 224:129-138.

Yoon RH, Cha SY, Wei B, Roh JH, Seo HS, Oh JY, Jang HK. 2014. Prevalence of Salmonella isolates and antimicrobial resistance in poultry meat from South Korea. J Food Prot 77:1579-1582.

Yulistiani R, Praseptiangga D. 2019. Occurrences of Salmonella spp. and Escherichia coli in chicken meat, intestinal contents and rinse water at slaughtering place from traditional market in Surabaya, Indonesia. IOP Conf Ser Mater Sci Eng 633:012007. 